\title{
'Taking Flight, Not Taking Fright?': The National Court As a Full Partner in the Enforcement of the State Aid Discipline
}

A central feature of the Union's legal order is the decentralised manner in which Union law is enforced. Although Article 17(1) of the Treaty on European Union ('TEU') requires the Commission to ensure that the provisions of the Treaties and the measures adopted by the institutions are applied, it is simply not possible for the Commission to investigate all alleged breaches of Union law, or to vindicate in all circumstances the rights created by Union law for individuals and for firms. Instead, those individuals, companies and national authorities have a central role, indeed the primary role, in ensuring the enforcement of Union law.

In the absence of enormous resources that would be needed to decide all litigation in which Union law could be invoked by those individuals, companies and national authorities, it is evident that the Union judicature is inherently unable to the sole judge of Union law. It is equally obvious that those who drafted the Treaty knew of that incapacity and that the enforcement mechanisms for Union law, in which the Commission has no monopoly on enforcement of Union law, result from their deliberate choice to ensure a shared role between national judges and the Court of Justice.

Those general features of the Union legal order apply with as much force to the rules making up the State aid discipline as they do to other realms of Union law. There is the obvious complication that the Treaty on the Functioning of the European Union ('TFEU') divides the substance of those rules into two: existence, governed by Article 107(1) TFEU and which is, because of the linkage with the notification and stand-still obligations set out in Article 108(3) TFEU, a matter on which the national courts play the role of full-fledged enforcer of the rules; and compatibility, governed by Article 107(2) and (3) TFEI and which is within the sole purview of the Commission. However, if there is no notification requirement for a given State aid measure (which is the case for categories of aid that have been block-exempted), the division of competences in respect of compatibility becomes blurred.

The role of national judges in respect of State aid is growing in terms of practical importance. While the first principles that both create and limit the competences of judges in the Member States' courts are unchanged, the environment in which those principles come into play has shifted. Knowledge of the State aid rules seems to have become more widespread, which is an unsurprising side-effect of the greater prominence of the Commission's decisions in the consciousness of citizens and of businesses (and of the media). The range of measures that are perceived as potentially falling within the ambit of State aid, as a notion, has widened as now well-established case-law on infrastructure, on taxation and on compensation awards filters into the awareness of advocates and advisers seeking useful tools with which to advance their clients' interests.

The result is that the national judge becomes steadily more important as an active mover in the shaping and refinement of the notion of State aid. The active dialogue between the Court of Justice and referring courts conducted in the framework of Article 267 TFEU sees more ref- 
erences being made, further clarifications being offered, and additional queries being generated across all the constituent elements of State aid. Looking back at the past three years, we have the national courts and the Court of Justice exploring together issues such as the presence of economic activity, ${ }^{1}$ ancillarity, ${ }^{2}$ the existence of State resources, ${ }^{3}$ the application of the market economy operator test, ${ }^{4}$ the selectivity of advantages provided under a State measure, ${ }^{5}$ and whether a measure is capable of affecting trade between Member States. ${ }^{6}$

Earlier we touched on another element that, although it is not novel in terms of first principles, seems to be becoming a major shaper of the State aid landscape, namely the elimination of the notification requirement for those aids that are block-exempted. Some commentators have voiced concern that the increased number in the grounds of exemption and the widened scope of those grounds previously established could lessen control over State aid, since there would be no direct surveillance by the Commission. An obvious riposte to those fears is that the enhanced transparency and publicity requirements that apply as regards such block-exempted measures at least mitigate those risks, but it is fair to note that while transparency may be a deterrent it cannot be an absolute safeguard nor can it substitute for an effective enforcement of the rules. The increased monitoring activities of the Commission offer one ex post remedy, but the national courts also have a role to play. They are, moreover, already playing that role, if the preliminary rulings that they seek offer us any insight as to what is happening in practice. The references on the notion of 'firm in difficulty' in the 2008 General Block Exemption Regulation in Nerea ${ }^{7}$ and on the need under the same Regulation for any purportedly block-exempted aid scheme to have a reference in the Official Journal in Dilly's Wellnesshotel ${ }^{8}$ show that national courts actively police the State aid discipline as regards issues linked to compatibility (without ruling on compatibility as such).

It is well-known that the Commission sought to encourage the national courts to take up as fully as they could their role as enforcers of the rights and obligations flowing from Article 108(3) TFEU and their duties in the context of recovery proceedings. The 2009 Commission Notice on the enforcement of State aid by national courts offered a synthesis of the case-law of the Union courts on the responsibilities and powers of national judges in that respect, and also sought to facilitate their tasks by setting out procedures by which national court may ask the Commission for information that it holds or may seek from the Commission an opinion concerning the application of the State aid rules.

Those mechanisms have been given a legislative underpinning in what is now Article 29(1) of the Procedural Regulation. ${ }^{9}$ The opinions sought by national courts and the resulting judgment of the national courts are now provided on the website of DG COMP, ${ }^{10}$ and the range of

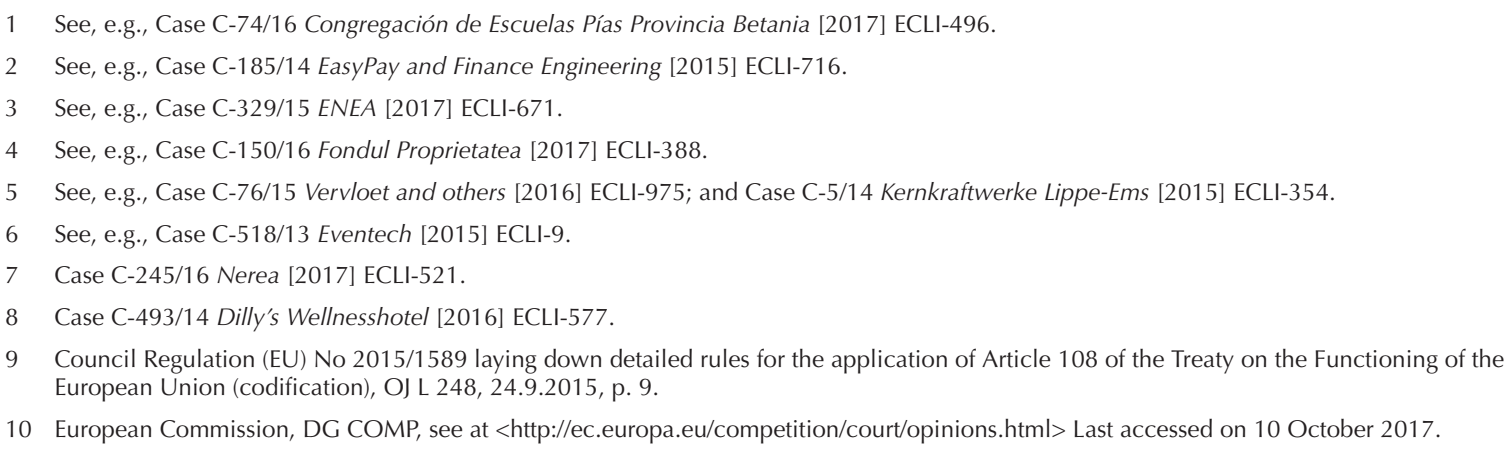


questions posed indicates that national courts make some use of the facility provided to them by the Commission. The Commission has, in addition, taken a more proactive stance towards national courts since the Union legislator created the possibility for it to offer amicus curiae submissions of its own motion, a power laid down in Article 29(2) of the Procedural Regulation. Here again, the website of DG COMP now brings together those submissions and the subsequent rulings of the national courts. ${ }^{11}$

The development of those tools over the past ten years and the greater efforts made by the Commission to raise awareness of them amongst judges and practitioners in the Member States builds on the adage that in the Union's legal order, the national judge is the ordinary judge of Union law. There are a series of factors that have increased the prominence of the national judiciaries in the field of State aid over recent years and every indication is that those same trends will not ease off. We have waited a long time for the enforcement of State aid law to become a robust force in national litigation, to move outside its long-standing role of last (and often desperate) defence to a claim of liability to pay one or another form of tax. Finally, with the active engagement of Union and national courts, the Commission and the wider legal profession, it could be that we now have 'lift-off'.

Leo Flynn*

11 European Commission, DG COMP, amicus curiae, see at <http://ec.europa.eu/competition/court/amicus_curiae_interventions.html> Last accessed on 10 October 2017.

* Leo Flynn, Legal Adviser, European Commission. All views expressed are personal. 